DOI: 10.15503/onis2014-171-179

\title{
ANALIZA BADAŃ NAD RODZINAMI HOMOSEKSUALNYMI
}

\author{
Dorota Dolata, e-mail: dorotata464@02.pl \\ Uniwersytet im. Adama Mickiewicza w Poznaniu \\ Wieniawskiego 1, 61-712 Poznań
}

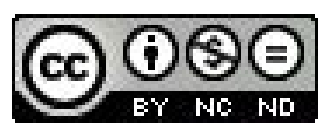

\section{STRESZCZENIE}

Celem niniejszego artykułu jest przedstawienie, a także analiza badań dokonanych przez różnych badaczy na rodzinach homoseksualnych wychowujących dzieci. Tematyka ta zostanie przeanalizowana na kilku płaszczyznach korelujących ze sobą: funkcjonowania rodziny, przebiegu interakcji i sposobu komunikacji pomiędzy poszczególnymi członkami, jakości funkcjonowania psychospołecznego dzieci z tych rodzin, jak również orientacji seksualnej dorosłych osób, wychowanych $w$ takich rodzinach.

Słowa kluczowe: teoria systemowa, rodzina homoseksualna, dzieci, wychowanie, orientacja seksualna, funkcjonowanie psychospołeczne

Analysis of researches on homosexual parents

\section{Abstract}

The aim of this article is to present, as well as the analysis of the research carried out by researchers from different researchers on the homosexual families who are bringing up children. This subject will be examined at several levels correlated with each other: family functioning, process of interaction and the mode of communication between the members, the quality of the psychosocial functioning of children from these families, as well as sexual orientation adults who were growing up in homosexual families.

Key words: theory system, homosexual family, children, bringing up, sexual orientation, psychosocial functioning

\section{WSTĘP}

W wielu krajach Unii Europejskiej, pary tej samej płci mogą spełniać się w roli rodziców i legalizować swe związki. Na podstawie różnych badań przeprowadzonych przez uczonych z wielu krajów, zostaną opisane podstawowe aspekty funkcjonowania rodziny homoseksualnej, jako całości oraz poszczególnych jej członków (dzieci w niej się wychowujących). Będą przedstawione wyniki badań dotyczące dzieci wychowywanych w rodzinach "tęczowych", ich funkcjonowania psychospolecznego, przekazywanych im wartości w rodzinie i internalizacji tych wartości, ich orientacji seksualnej oraz radzenia sobie w środowisku szkolnym i z rówieśnikami. Problematyka rodzin homoseksualnych zostanie przedstawiona dzięki przestudiowaniu różnych artykułów zagranicznych uczonych i wyników ich badań odnoszących się do funkcjonowania tych rodzin.

\section{WPROWADZENIE DO ANALIZY BADAŃ}

Najczęściej pojawiającym się pytaniem, a jednocześnie obawą związaną z wychowywaniem się dzieci w rodzinach homoseksualnych, jest to, czy dzieci te będą orientacji homoseksualnej. Nawiązując do badania funkcjonowania rodzin tradycyjnych, najczęściej zwraca się uwagę najakość życia członków struktury rodzinnej poprzez analizę, między innymi, ich funkcjonowania psychospołecznego. Rzadko jednak zadaje się to samo pytanie, które stawia się w analizie rodzin homoseksualnych („,zy dzieci te będą homoseksualistami?”), a zapomina się, że zdarza się, iż dzieci z rodzin heteroseksualnych przyjmują odmienną niż rodzice orientację seksualną.

Tym, co wydaje się być ważne i absorbujące, to zagadnienie, które stawia się często również przy badaniu rodzin tradycyjnych - czy rodzina homoseksualna jest w stanie zapewnić odpowiednie i zdrowe środowisko do wychowywania swego potomstwa, tudzież dzieci adoptowanych, i zjakimi problemami musi sobie poradzić, by satysfakcjonująco przejść kolejne cykle życia rodzinnego ${ }^{1}$, a także w jaki sposób tego dokonuje?

W niniejszym artykule, wśród rodzin "tęczowych" będą te, w których rodzicami jest dwóch mężczyzn (wychowujących dzieci adoptowane, bądź stanowiących dla tych dzieci rodzinę zastępczą) lub dwie kobiety mające dziecko z poprzed-

1 K. Ostoja-Zawadzka, Cykl życia rodzinnego, [w:] B. De Barbaro (red.), Wprowadzenie do systemowego rozumienia rodziny, Kraków 1997, s. 19-29. 
niego związku heteroseksualnego, czy kobiety zapłodnione in vitro. Oprócz przytoczenia, wspomnianych we wstępie, wyników różnych badań prezentowanych w publikacjach zagranicznych, które zostały przeprowadzone przez badaczy ściśle zajmujących się problematyką funkcjonowania rodzin homoseksualnych, zostaną również ukazane niektóre wypowiedzi Judith Stacey², socjolog pracującej w Uniwersytecie w Nowym Jorku i wieloletniej badaczki rodzin homoseksualnych.

\section{CharaKterystyka RODZiny homoseKSUALNeJ}

Każda rodzina posługuje się unikatowymi regułami i strategiami postępowania ${ }^{3}$. Są one wyjątkowe, ponieważ każdy system tworzą inni ludzie wzajemnie na siebie oddziałujący w wyjątkowy dla nich sposób, przekazując jednocześnie normy postępowania swoim dzieciom4.

Jak się okazało, rodziny homoseksualne w opiece i wychowywaniu dzieci, pod niektórymi względami wyróżniają się spośród pozostałych rodzin. Przede wszystkim, w przeważającej większości, rodziny „tęczowe” są rodzinami egalitarnymi. Dzieci uczy się sprawiedliwego i równego podziału obowiązów. Badania ${ }^{5}$ wykazały, że rodzice dzielą się tak samo zakresem zadań, zarówno tych dotyczących prac domowych, jak również tych związanych z podejmowaniem decyzji dotyczących wychowywania i opieki nad dziećmi. Nie występuje ścisły podział na realizację tylko wybranych obowiązków przez jednego członka systemu rodzinnego ${ }^{6}$. Ze stylem egalitarnym łączy się także nabywanie i nauka wielu kompetencji społecznych. Dziecko ma okazję nabycia umiejętności komunikacji i kompromisu podczas dyskusji dotyczącej chociażby podziału obowiązków. Ponadto, wychowanek uczy się, że nie ma selekcji na ludzi lepszych i gorszych, każdy ma pewne zobowiązania, z których powinien się wywiązywać.

Wykazano także ${ }^{8}$, że dziewczynki i chłopcy z rodzin homoseksualnych, są bardziej elastyczni w funkcjonowaniu w różnych rolach społecznych związanych z płcią. Z większą swobodą potrafili zaadaptować się do sytuacji, które wymagały zachowania się w sposób stereotypowo uważany za męski, czy damski (na przykład dziewczęta z rodzin homoseksualnych swobodnie posługiwały się młotkiem). Wychowankowie rodzin "tęczowych" wiedzieli, co oznacza tradycyjne rozumienie roli męskiej i żeńskiej i przypisywanych im zadań, jednak stwierdzali z całym przekonaniem, że każda osoba, niezależnie od płci, może wykonywać te same obowiązki. Potrafili zinterpretować, jakie zachowania uważa się za te, które teoretycznie powinny być przeznaczone przede wszystkim kobietom (za przykład podano karmienie dzieci przez mamy), a które mężczyznom (bawienie się samochodami). Jednak z większą częstotliwością niż ich rówieśnicy z rodzin heteroseksualnych, wnioskowali, że zarówno dziewczynka, jak i chłopiec mogą naprzemiennie bawić się lalkami i samochodami, a żadna z zabaw/zabawek nie jest przypisana tylko i wyłącznie kobietom, czy mężczyznom?

Należy wspomnieć, że Amerykańskie Towarzystwo Psychologiczne orzekło, iż jakość wychowywania, jak również skuteczność rodzicielstwa, nie mająz żadnego powiązania z orientacją seksualną rodziców, ponieważ zarówno lesbijki, jak również geje, potrafią i zapewniają warunki sprzyjające rozwojowi swoich dzieci ${ }^{10}$.

Ch. J. Patterson ${ }^{11}$ przeprowadziła badanie, w którym wzięło udział dwadzieścia sześć rodzin homoseksualnych, tworzonych przez dwie kobiety wychowujące co najmniej jedno dziecko w wieku pomiędzy czwartym a dziewiątym rokiem życia. Okazało się, że zarówno matka biologiczna, jak i jej partnerka nie różniły się względem zaangażowania w utrzymaniu gospodarstwa domowego, jak również starały się równomiernie rozdzielać obowiązki pomiędzy siebie. Jedyną zauważalną różnicą było to, że matka biologiczna była bardziej zorientowana w swych działaniach na opiece nad dzieckiem, z kolei jej partnerka częściej zajmowała się organizacją różnego rodzaju opłat (np. czynszu za mieszkanie). Jednak ogólna satysfakcja z relacji partnerskiej, na płaszczyźnie wychowywania dzieci, została oceniona wysoko przez wszystkie kobiety biorące udział w badaniu ${ }^{12}$.

2 L. Cooper, P. Cates, Too High a Price: The Case Against Restricting Gay Parenting, New York 2006, s. 34-38.

3 M. Plopa, dz. cyt., s. 18

4 Tamże, s. 18.

5 M. del Mar González, F. López, dz. cyt., s. 10- 11

6 Tamże, s. 10- 11 .

7 Tamże, s. 10-12

8 Tamże, s. 11- 13 .

9 Tamże, s. 12.

10 A. Kaim, A. Gugniewicz, Edukacja bez wykluczenia. ABC wsparcia dla rodzin zagrożonych wykluczeniem społecznym. Informator dla nauczycieli i nauczycielek, Gdańsk 2007, s. 17

11 Ch. J. Patterson, Families of the lesbian baby boom: Parents' division of labor and children's adjustment, "Developmental Psychology" 1995, nr 31, s. $115-123$.

12 Tamże, s. 115-123. 
Okazuje się, że rodzice orientacji homoseksualnej promują modele płciowe mniej zróżnicowane pod względem powinności do określonych i ściśle skategoryzowanych (w zależności od płci) zadań. Podkreślają ważność sprawiedliwego podziału obowiązków w rodzinie i wychowywania swoich dzieci. Owocuje to u ich potomstwa wykazywaniem się mniejszą dozą kategoryzacji płciowej wśród rówieśników, jak również przekonaniem o równości wszystkich ludzi niezależnie od płci'

\section{INDYWIDUALNE PROFILE PSYCHOLOGICZNE RODZICÓW HOMOSEKSUALNYCH}

Niewątpliwie, w ocenie środowiska domowego, jako prawidłowego, bądź nie, dla zdrowego rozwoju wychowujących się w nim dzieci, niezbędna jest $\mathrm{m}$. in. indywidualna ocena całokształtu funkcjonowania psychicznego ich rodziców.

Naukowcy (María del Mar González i Francisca López) z Uniwersytetu w Sevilli, przebadali dwadzieścia osiem rodzin homoseksualnych wychowujących dzieci w przedziale wiekowym między trzecim a szesnastym rokiem życia. Osiemnaście z tych rodzin wychowywało dzieci z poprzednich związków heteroseksualnych, pięćz nich posiadało dzieci poczęte w wyniku sztucznego zapłodnienia, a ostatnie pięcioro dzieci było adoptowanych. Spośród wszystkich rodzin, $\mathrm{w}$ dwudziestu jeden z nich, dzieci mieszkały z kobietami orientacji homoseksualnej, a w siedmiu z mężczyznami orientacji homoseksualnej. Na podstawie wyników badań wykazano, że przebadani rodzice homoseksualni prezentowali wysoki poziom własnej samooceny i nie zauważono, by prezentowali jakiekolwiek problemy ze zdrowiem psychicznym ${ }^{14}$.

Podobne wyniki badań uzyskano w innym projekcie badawczym realizowanym również w Hiszpanii w latach 2005 i 2007. Porównywano funkcjonowanie rodzin homoseksualnych na tle pozostałych struktur rodzinnych (zrekonstruowanej, niepełnej, adopcyjnej, tradycyjnej i wielopokoleniowej). Rodzice homoseksualni nie prezentowali żadnych oznak nieprzystosowania społecznego, problemów ze zdrowiem psychicznym, czy w aspekcie funkcjonowania psychospołecznego. Podobnie jak pozostali, troszczyli się o zdrowie swoich dzieci i martwili o ich przyszłość edukacyjną. W wychowaniu swych pociech przykładali jednak wielką wagę do tolerancji oraz szacunku w stosunku do wszystkich osób i w tym aspekcie wyróżniali się spośród rodzin heteroseksualnych ${ }^{15}$.

Badacze David K. Flaks, Ilda Fischer, Frank Masterpasqua oraz Gregory Joseph ${ }^{16}$ porównywali funkcjonowanie piętnastu rodzin homoseksualnych z rodzinami heteroseksualnymi. Rolę rodziców w rodzinach „tęczowych" pełniły dwie kobiety, wychowujące dzieci w przedziale wiekowym między trzecim a dziewiątym rokiem życia. Wychowankowie rodzin homoseksualnych byli poczęci na skutek sztucznego zapłodnienia. D. K. Flaks, I. Fischer, F. Masterpasqua oraz G. Joseph analizowali funkcjonowanie rodzin pod kątem przystosowania społecznego dzieci oraz ich funkcjonowania poznawczego, a także badalijakość relacji pomiędzy rodzicami. Wykazano, że pomiędzy tymi dwoma modelami rodziny (homoseksualną a heteroseksualną) nie występowały znaczące różnice, mogące rzutować na jakość funkcjonowania ich wychowanków ${ }^{17}$.

W innych badaniach, przeprowadzonych na dwustu pięćdziesięciu sześciu parach lesbijskich oraz gejowskich tworzących własne rodziny, wykazano, że tylko niewielka ich ilość stosowała jakiekolwiek kary psychiczne, jak na przykład autorytarne techniki dyscyplinujące dzieci, raczej używali metod opartych na komunikacji i argumentacji1 .

Wspomniana na początku artykułu J. Stacey jest zdania, że rodzice homoseksualni (mężczyźni, bądź kobiety) są co najmniej tak samo efektywni i opiekuńczy w wychowywaniu swych pociech, jak rodzice heteroseksualni, a dzieci dorastające w takich rodzinach są emocjonalnie zdrowe i również przystosowane społecznie ${ }^{19}$.

\section{ASPEKT EDUKACYJNY}

Oprócz powszechnie rozumianej edukacji szkolnej, bardzo ważna jest także ta, przygotowująca dzieci do możliwości rozwijania nabytych wcześniej kompetencji. W związku z czym, rodzice pehnią niezwykle istotną funkcję w przygotowaniu swych pociech (rozwijanie motoryki małej oraz dużej poprzez chociażby naukę chodzenia) do dalszego, bardziej samodzielnego nabywania wtórnych kompetencji (dzięki prawidłowemu rozwojowi motoryki małej, dzieci będą zdolne

13 M. del Mar González, F. López, dz. cyt., s. 11-13; Ch. J. Patterson, dz. cyt., 115-123.

14 M. del Mar González, F. López, ¿Qué hemos aprendido de las familias homoparentales en España?, http://www.fsc.ccoo.es/comunes/recursos/99922/doc21513 Que hemos_aprendido_de las familias_homoparentales_en Espana_pdf, 11.03.2014, s. 3-4.

15 A. Oliva, Á. Parra, L. Antolín-Suárez, E. Arranz, J. L. Martín, M. Lamb, Diversidad familiar y desarrollo psicológico: un estudio pionero realizado en España, [w:] Arranz Freijo E., Oliva Delgado A. (red.), Desarrollo psicológico en las nuevas estructuras familiares, Madrid 2010, s. 143-156.

16 D. Flaks, I. Ficher, F. Masterpasqua, G. Joseph, Lesbians choosing motherhood: A comparative study of lesbian and heterosexual parents and their children, "Developmental Psychology" 1995, nr 31, s. 104-114.

17 Tamże, s. 104-114.

18 C. J. Patterson, Lesbian and gay parenting, Washington 2005, s. 8.

19 L. Cooper, P. Cates, dz. cyt., s. 34-38. 
chociażby prawidłowo trzymać długopis i zacząć naukę pisania).

Wyniki badań naukowców z Sevilli20 ${ }^{20}$ wykazały, że rodzice homoseksualni byli całkowicie zdolni, by zagwarantować swoim podopiecznym odpowiednie środowisko do edukacji i rozwoju. Przedstawiali wysoki poziom wiedzy dotyczącej prawidłowego funkcjonowania i dojrzewania dzieci oraz wiedzieli jakie można przedsięwziąć środki w celu stworzenia im satysfakcjonującej płaszczyzny, na której mogłyby rozwijać swoje zdolności bądź pokonywać ewentualne trudności. Ponadto, rodzice ci wykazywali w stosunku do swych pociech dużą dozę empatii i komunikacji, poprzez stawianie pewnych norm i reguł współżycia domowego opartych na argumentacji i kompromisie ${ }^{21}$.

Wyniki badań realizowanych przez Alfredo Oliva, Águeda Parra, Lucía Antolín-Suárez, Enrique Arranz, Juan Luis Martín oraz Michael Lamb² są tożsame. Badacze ci analizowali wypowiedzi nauczycieli uczących dzieci, które wychowywały się w rodzinach homoseksualnych oraz ich rodziców. Wykazano, że wychowankowie dorastający w rodzinach "tęczowych" nie sprawiają żadnych problemów edukacyjnych, jak również problemów w kontaktach z rówieśnikami23.

\section{INTERAKCJE WYSTĘPUJĄCE W RODZINIE}

Niewątpliwie tym, co bardzo ważne i ma duży wpływ na prawidłowe funkcjonowanie i rozwój wszystkich osób w rodzinie, jest występująca w niej jakość interakcji i sposobu komunikowania się, charakteryzujące się szacunkiem, zaufaniem i akceptacją w stosunku do drugiej osoby ${ }^{24}$. Jak te interakcje i sposoby komunikowania się przebiegają w rodzinie homoseksualnej?

Wykazano, że członkowie takiej rodziny utrzymują zdrowe i harmonijne relacje, w których wspiera się siebie nawzajem i stawia na piedestale więzi rodzinne, jednocześnie umożliwiając i szanując indywidualność i autonomię każdej jednostki. W rodzinach tych normy postępowania są wyraźnie i jednoznacznie określone, a poszczególni członkowie rodziny potrafią w sposób elastyczny zaadaptować się do nowych warunków i okoliczności² ${ }^{25}$ W związku z czym, można wywnioskować, że $\mathrm{w}$ większości przebadanych rodzin, ich granice zewnętrzne są względnie przepuszczalne ${ }^{26}$, a rodziny te potrafią dostosować się do zmieniających się warunków, umożliwiając efektywniejsze radzenie sobie z napotkanymi problemami ${ }^{27}$.

Ważna również, dla zdrowego i harmonijnego rozwoju dzieci, jest jakość ich kontaktów z dziadkami. Badania prowadzone przez Charlotte J. Patterson wraz ze współpracownikami, analizujące funkcjonowanie rodzin homoseksualnych, wykazały, że dzieci par gejów i lesbijek utrzymują regularne kontakty z rodzicami swych opiekunów²8.

Z kolei Nanette Gartrell wraz ze współpracownikami prowadzili longitudinalne badania nad rodzinami homoseksualnymi tworzonymi tylko przez pary lesbijskie, $\mathrm{w}$ których kobiety znajdowały się $\mathrm{w}$ wieku między dwudziestym dziewiątym, a czterdziestym siódmym rokiem życia, wychowujące dzieci, poczęte na skutek sztucznego zapłodnienia. Wykazali oni, że 63\% spośród wychowanków tych rodzin utrzymywało przyjazne relacje z dziadkami, którzy akceptowali strukturę rodzinna, w której wychowywali się ich wnukowie ${ }^{29}$.

Inne ciekawe badania, którym poddały się matki heteroseksualne oraz homoseksualne, przeprowadzili Megan Fulcher, Raymond Chan, Barbara Raboy oraz Ch. J. Patterson, analizując jakość relacji pomiędzy dziećmi poczętymi na skutek sztucznego zapłodnienia a ich dziadkami. W badaniu wzięło udział pięćdziesiąt pięć rodzin homoseksualnych, tworzonych przez lesbijki oraz dwadzieścia pięć rodzin heteroseksualnych. Nie wykazano różnic w częstości kontaktów wnuków ze swoimi dziadkami, niezależnie od tego zjakiej rodziny się wywodziły. Zauważono jednak, że zarówno dzieci $\mathrm{z}$ rodzin heteroseksualnych, jak i te z rodzin homoseksualnych, utrzymywały częstszy kontakt z rodzicami swojej biologicznej matki, aniżeli jej partnera, czy partnerki ${ }^{30}$.

\footnotetext{
20 M. del Mar González, F. López, dz. cyt., s. 1-22.

21 Tamże, s. 5-6.

22 A. Oliva, Á. Parra, L. Antolín-Suárez, E. Arranz, J. L. Martín, M. Lamb, dz. cyt., s. 134-156.

23 Tamże, s. 148-150.

24 Tamże, s. 148-149.

25 M. del Mar González, F. López, dz. cyt., s. 11-12.

26 M. Plopa, Psychologia rodziny, Kraków 2005, s. 25.

27 M. del Mar González, F. López, dz. cyt., s. 11-12.

28 Ch. J. Patterson, dz. cyt., s. 11.

29 N. Gartrell, A. Banks, N. Reed, J. Hamilton, C, Rodas, A. Deck, The National Lesbian Family Study: 3. Interviews with mothers of five-year-olds, "American Journal of Orthopsychiatry" 2000, nr 70(4), s. 542-548.

30 M. Fulcher, R. W. Chan, B. Raboy, Ch. J. Patterson, Contact with grandparents among children conceived via donor insemination by lesbian and heterosexual mothers., "Parenting: Science and Practice" 2002, nr 2, s. 61-76.
} 
Opinia dzieci wychowujących się w rodzinach homoseksualnych w Hiszpaniiil potwierdza powyższy opis. Dzieci mówily, że czują się akceptowane przez swoich rodziców i chciane, ponadto, że wykazywali oni o nich troskę i dodawali otuchy w usamodzielnianiu się i nabywaniu nowych umiejętności i kompetencji charakterystycznych dla kolejnych faz rozwojowych, a także starali się, by te utrzymywały stały kontakt ze swoimi dziadkami32.

\section{ROZWÓJ PSYCHOLOGICZNY DZIECI WYCHOWYWANYCH W RODZINIE HOMOSEKSUALNEJ}

To, co zazwyczaj najbardziej absorbuje i zastanawia w problematyce wychowywania dzieci w rodzinie homoseksualnej, to ich późniejsza tożsamość seksualna oraz ich rozwój (czy będzie przebiegać prawidłowo, czy nie pojawią się jakieś odstępstwa od normy, bądź zaburzenia zachowania, powodowane między innymi potencjalną możliwością odrzucenia w grupie rówieśniczej).Zostało przeprowadzonych wiele badań odnoszących się do tej problematyki. Wyniki niektórych z nich zostaną przytoczone poniżej.

Przeprowadzono badania sprawdzające funkcjonowanie psychiczne dzieci z rodzin homoseksualnych w różnych obszarach: kompetencji społecznych, edukacyjnych i umiejętności integracji społecznej, a także przestudiowano ich poziom samooceny i umiejętność przystosowania emocjonalnego i behawioralnego ${ }^{33}$.

W projekcie badawczym realizowanym przez wspomnianych już badaczy z Uniwersytetu z Sevilli34 wykazano, że dziewczynki i chłopcy, wychowujący się w rodzinach tworzonych albo przez dwie lesbijki, albo dwóch gejów, prezentowali średni, bądź wysoki poziom samooceny (na skali 1-4, gdzie średnia ocena plasowała się na 3,2). Osiagnięte wyniki były bardzo zbliżone do tych (nie różniły się znacząco), uzyskanych przez ich kolegów i koleżanki, z którymi były porównywane ${ }^{35}$.

W podobny sposób, w tych samych badaniach, oceniono przystosowanie emocjonalne i behawioralne pod kątem wystąpienia potencjalnych objawów depresji, wyobcowania, zaburzeń zachowania itp. Nie zauważono wśród tych dzieci problemów we wspomnianych powyżej obszarach, takich, które mogłyby być niepokojące i sygnalizować możliwości pojawienia się potencjalnych trudności. Punktacja na skali plasowała się poniżej kryterium wyznaczającego granicę wystąpienia problemów przystosowawczych. Porównując uzyskane przez te dzieci wyniki z ich rówieśnikami, również nie stwierdzono żadnych różnic ${ }^{36}$.

Inne badania przeprowadziła Ch. J. Patterson na trzydziestu siedmiu rodzinach homoseksualnych, które tworzyły pary lesbijskie, bądź kobiety orientacji homoseksualnej samotnie wychowujące dzieci. Ich wychowankowie byli w wieku pomiędzy czwartym, a dziewiątym rokiem życia. Szeroko analizowano funkcjonowanie dzieci na różnych płaszczyznach. Wykazano, że podopieczni z tych rodzin prezentowali więcej symptomów stresu, aczkolwiek również wyższy poziom dobrego samopoczucia ${ }^{37}$.

Podobne wyniki (pod względem jakości funkcjonowania dzieci z rodziny homoseksualnej) uzyskali inni badacze, już wcześniej wzmiankowani, z Hiszpanii3 ${ }^{38}$, porównujący sześć różnych modeli rodzinnych. Wykazali, że dzieci z rodzin "tęczowych" uzyskały najniższy na skali poziom prezentowanych przez nie potencjalnych zachowań problematycznych w szkole i wśród rówieśników, jak również problemów emocjonalnych ${ }^{39}$.

Wiele badań koncentruje się na porównywaniu grupy rodzin homoseksualnych, składających się z par lesbijskich wychowujących dzieci, z grupą rodzin heteroseksualnych. Sprawdza się, czy dzieci z rodzin „tęczowych” przejawiaja wzmożony niepokój, bądź czy występują u nich problemy ze zdrowiem psychicznym. Jednak w tych dwóch aspektach (potencjalnych problemów ze zdrowiem psychicznym, czy objawów wzmożonego stresu), nie wykazano różnic pomiędzy wychowankami z rodzin homoseksualnych a tymi z rodzin heteroseksualnych ${ }^{40}$.

Powyższe badania są zgodne z wieloma innymi, przeprowadzanymi w różnych krajach, które także odnosily się do analizy funkcjonowania dzieci z rodzin homoseksualnych, sprawdzając, czy wychowankowie rodzin "tęczowych"

31 M. del Mar González, F. López, dz. cyt., s. 1-22.

32 N. Gartrell, A. Banks, N. Reed, J. Hamiliton, C, Rodas, A. Deck, dz. cyt. s. 542- 548; M. Fulcher, R. W. Chan, B. Raboy, C. J. Patterson dz. cyt. s. 61-76; M. del Mar González, F. López, dz. cyt. s. 1-22.

33 M. del Mar González, F. López, dz. cyt., s. 1-22

34 Tamże, s. 10.

35 Tamże, s. 14.

36 Tamże, s. 14-15.

37 Ch. J. Patterson, Children of the lesbian baby boom: behavioral adjustment, self- concepts, and sex- role identity, [w:] B. Greene, G. Herek (red.), Contemporary perspectives on lesbian and gay psychology: Theory, research and application, Beverly Hills 1994, s. 156- 175.

38 A. Oliva, Á. Parra, L. Antolín-Suárez, E. Arranz, J. L. Martín, M. Lamb, dz. cyt., s. 143-156.

39 Tamże, s. 149.

40 L. Cooper, P. Cates, dz. cyt., s. 34-38.

OGRODY NAUK I SZTUK NR 2014 (4) 
wykazują symptomy świadczące o potencjalnie występujących problemach ze zdrowiem psychicznym. Jak wzmiankują badacze ${ }^{41}$, dzieci te prezentują zbliżony profil psychologiczny do potomstwa rodzin heteroseksualnych, jak również nie majążadnych problemów mogących uniemożliwiać im normalne i satysfakcjonujące funkcjonowanie psychospołeczne ${ }^{42}$.

\section{INTEGRACJA RÓWIEŚNICZA DZIECI Z RODZIN HOMOSEKSUALNYCH}

Tym, co często martwi i zastanawia jest fakt, czy podopieczni z rodzin „tęczowych" nie będą marginalizowani zarówno przez społeczność lokalna, jak również przez grono współtowarzyszy zabawy.

Wykazano $^{43}$, że dziewczynki i chłopcy mający rodziców orientacji homoseksualnej, są dobrze zintegrowani i akceptowani w gronie rówieśniczym, które nie stosuje w stosunku do nich form odrzucenia, czy wykluczenia społecznego. Ponadto, podopieczni rodzin "tęczowych" zazwyczaj nawiązują bliską relację z co najmniej jedną osobą pełniącą rolę przyjaciela, przy którym czują się całkowicie zadowolone i z którym dzielą swoje sekrety i problemy" ${ }^{44}$.

María del Mar González oraz F. López podczas analizy funkcjonowania drugiej grupy badanych przez nich osób (łącznie szesnastu badanych - młodzież i osoby dorosłe, w wieku od siedemnastu do trzydziestu jeden lat), pytały o doświadczenia związane z integracją społeczna. Tylko jedna osoba z szesnastu stwierdziła, że była obiektem kpin ze strony środowiska, przez to, w jakiej strukturze rodzinnej się wychowywała. Pozostałe piętnaście osób nie pamiętało, by przydarzyła im się jakakolwiek sytuacja świadcząca o ich marginalizacji, czy obrazie przez resztę społeczeństwa lokalnego $0^{45}$.

Problematykę kontaktów rówieśniczych, pomiędzy dziećmi wychowującymi się w rodzinach homoseksualnych, tworzonych przez pary kobiece, a dziećmi wychowującymi się w rodzinach heteroseksualnych, analizowała również Susan Golombock wraz ze współpracownikami. Zespół badawczy porównywał funkcjonowanie trzydziestu siedmiu dzieci w wieku od piątego do siedemnastego roku życia z trzydzieściorgiem ośmiorgiem dzieci z rodzin heteroseksualnych. Wykazali, że relacje wychowanków rodzin "tęczowych" z kolegami i koleżankami były pozytywne (nie występowały jakiekolwiek formy agresji, odrzucenia). Pytano osobiście wychowanków rodzin homoseksualnych o to, czy są zadowoleni ze swych kontaktów z rówieśnikami. Odpowiedzieli, że są usatysfakcjonowani i nie chcieliby niczego zmieniać w tych relacjach ${ }^{46}$.

Inne badania longitudinalne ${ }^{47}$ (wspomniane już wcześniej w niniejszym artykule) na rodzinach homoseksualnych tworzonych przez pary kobiece, prowadzone przez N. Gartrell i współpracowników wykazały, że 87\% wychowanków tych rodzin posiada dobre relacje ze swoimi rówieśnikami, jedynie $18 \%$ było ofiarą dyskryminacji ze strony swoich kolegów i koleżanek ${ }^{48}$. Jak widać, tylko niewielka liczba dzieci wychowujących się w rodzinach homoseksualnych doświadczyła trudności w procesie integracji rówieśniczej. Jednak przeważająca ich liczba bez większych trudności odnajduje się w środowisku koleżeńskim ${ }^{49}$.

Aspekt integracji rówieśniczej oraz relacji z przyjaciółmi dzieci z rodzin homoseksualnych z pozostałymi dziećmi, najlepiej mogą ocenić oni sami. Dlatego poniżej zostanie przedstawiona wypowiedź dwudziestosześcioletniego mężczyzny wychowującego się w rodzinie „tęczowej” ${ }^{\prime 50}$ „ „Do mojego domu każdy przychodził... niektóre osoby bliższe i niektóre będące po prostu znajomymi, ale nigdy ani nie czułem potrzeby, by wyjaśniać, że »moja mama jest w związku z kobieta, wiedz to jak będziesz wchodził do mojego domu«, ani potrzeby ukrywania tego; (...) mieszkałem po prostu z moją matką i z Carmen"51.

Dzieci z rodzin homoseksualnych z reguły nie miały problemów z integracją rówieśnicza, jak również nie czuły się niechciane wśród towarzyszy zabaw. Jedynie niewielki ich odsetek doświadczył formy marginalizacji ${ }^{52}$. Bardzo istotne jest, by relacje z kolegami i koleżankami przebiegały harmonijnie, ponieważ tworzą one obszar, w którym można nabywać kompetencje społeczne i w dużej mierze stanowią o funkcjonowaniu jednostki w założonej przez nią w przyszłości

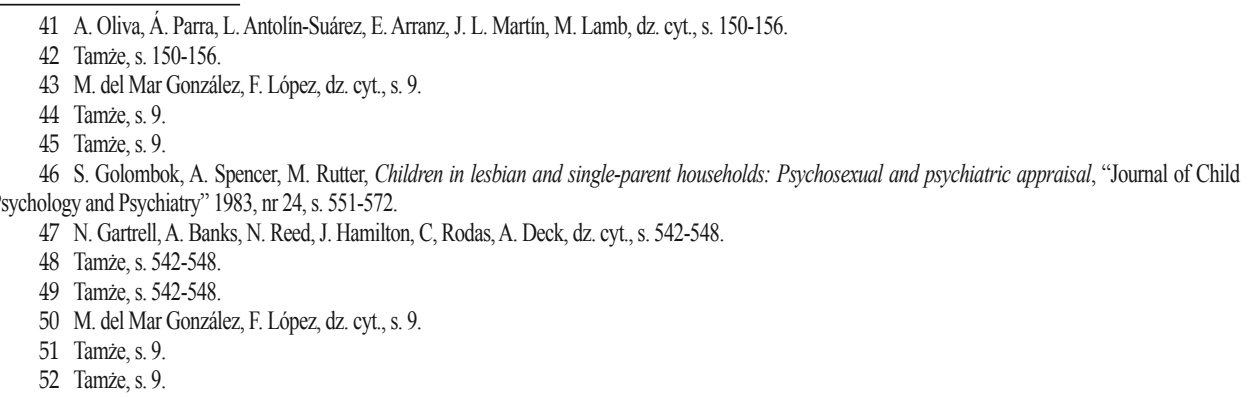


rodzinie, życiu towarzyskim, czy pracy ${ }^{53}$. By proces integracji rówieśniczej przebiegał bez większych trudności (marginalizacji, odrzucenia), potrzebna jest duża doza tolerancji i szacunku, czego nauczyć się można m. in. w domu rodzinnym.

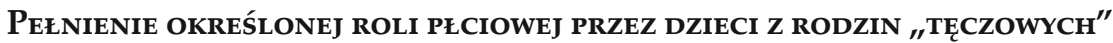

Jedną z głównych i najczęściej poruszanych kwestii dotyczących systemu rodziny homoseksualnej jest ta, odnosząca się do orientacji seksualnej ich dzieci. Można spotkać się z hipotezą o pewności rozwinięcia się z biegiem lat u dzieci tej samej orientacji seksualnej, co u ich rodziców. Czy wspomniane powyżej hipotezy się urzeczywistniają?

Jak dotychczas, udało się jedynie częściowo odpowiedzieć na to pytanie. W badaniach prowadzonych przez wspomniane już M. del Mar González i F. López ${ }^{54}$ pytano matki i ojców orientacji homoseksualnej, o aspekty behawioralne kultywowane w domu, które mogły mieć wpływ na pełnienie określonej roli płciowej5 przez dziecko (np. wyrażanie aprobaty zabawą lalkami jedynie w stosunku do dziewczynek). Większość z nich odpowiadała, że liberalnie wychowywała swoje dzieci w związku z ich przyszłymi preferencjami płciowymi. Nie wartościowali oni orientacji heteroseksualnej, jako gorszej, a homoseksualnej jako lepszej i odwrotnie. Starali się pozostawić wybór swoim dzieciom, szanując ich zdanie i będąc tolerancyjnymi względem różnych orientacji seksualnych. Nie gratyfikowali u swych dzieci zachowań mogących świadczyć o ich preferencjach homoseksualnych ${ }^{56}$. Analizując niniejsze badania, oprócz o wspomnianych stylach wychowywania, należałoby w nich także zwrócić uwagę, tudzież poszerzyć je o analizę wzorów zachowania prezentowanych przez rodziców, które odgrywają niebagatelną funkcję w przyjęciu przez dzieci określonej roli płciowej.

W jednym z już wspomnianych badań, prowadzonych przez S. Golombok, A. Spencer oraz M. Rutter ${ }^{57}$, porównywano stan emocjonalny, zachowania, relacje z rówieśnikami oraz rozwój psychoseksualny trzydziestu siedmiu dzieci i adolescentów w wieku od pięciu do siedemnastu lat, których opiekunami były osoby orientacji homoseksualnej wraz ze swymi partnerami oraz trzydziestu ośmiu dzieci z rodzin heteroseksualnych. W badaniu wzięło udział dwadzieścia siedem rodzin tworzonych przez pary lesbijskie oraz dwudziestu siedmiu samotnych rodziców orientacji heteroseksualnej. Nie wykazano różnic pomiędzy tymi dwoma grupami dzieci (tymi wychowywanymi w rodzinach „tęczowych", a tymi w rodzinach niepełnych z rodzicem orientacji heteroseksualnej) w płaszczyźnie ich tożsamości płciowej, identyfikacji z własną płcia, czy orientacją seksualną. Ponadto, sami wychowankowie rodzin homoseksualnych, nie wykazywali jakichkolwiek trudności ze swoją identyfikacją płciową i prezentowali zadowolenie z bycia chłopcem, czy dziewczynką ${ }^{58}$.

Kolejnym ważnym aspektem $\mathrm{w}$ problematyce funkcjonowania psychoseksualnego dzieci z rodzin homoseksualnych jest analiza ich zachowania, jako zgodnego, bądź nie, ze społecznymi wzorcami płci. Przykładowo, Martha Kirkpatrick wraz ze współpracownikami przeprowadzili badania, które wykazały, że dzieci z rodzin „tęczowych", tworzonych przez dwie kobiety, nie różniły się względem preferencji do zabaw, wyboru zabawek, czy aktywności w stosunku do swych rówieśników wychowywanych $\mathrm{w}$ rodzinach heteroseksualnych ${ }^{59}$.

Inne badania, nad zachowaniami związanymi ze społecznymi wzorcami płci, przeprowadził Richard Green ${ }^{60}$ wraz ze współpracownikami na trzydziestu córkach i dwudziestu sześciu synach wychowywanych przez pary lesbijskie z dwudziestoma ośmioma dziewczętami i dwudziestoma chłopcami wychowującymi się w rodzinach heteroseksualnych. Wiek osób znajdujących się w badanych grupach mieścił się w przedziale między trzecim a jedenastym rokiem życia. Nie znaleziono żadnych różnic pomiędzy dwoma badanymi grupami (dzieci z rodzin „tęczowych", a tych z rodzin heteroseksualnych) względem preferowanych programów telewizyjnych, czy gier i zabawek. Jedyną zauważalną różnicą było to, że dzieci wychowywane $w$ rodzinach homoseksualnych w mniejszym stopniu dokonywały podziału na zabawy stereotypowo korelujące z płcią (na przykład dziewczęta mogły bawić się zarówno lalkami, jak i samochodami, podobnie chłopcy). Również matki tych dzieci (pary lesbijskie) były bardziej liberalne, jeśli ich córki brały udział w zabawach stereotypowo

53 M. Bardziejewska, Okres dorastania. Jak rozpoznać potencjał nastolatków?, [w:] A. I. Brzezińska (red.), Psychologiczne portrety czlowieka, Gdańsk 2005, s. 346- 377 .

54 M. del Mar González, F. López, dz. cyt., s. 11-13.

55 M. Seligman, E. F. Walker, D. L. Rosenhan, Psychopatologia, Poznań 2003, s. 575.

56 M. del Mar González, F. López, dz. cyt., s. 11-13.

57 S. Golombok, A. Spencer, M. Rutter, dz. cyt., s. 551-572

58 Tamże, s. 551-572.

59 M. Kirkpatrick, C. Smith, R. Roy, Lesbians mothers and their children: A comparative survey, "American Journal of Orthopsychiatry" 1981, nr 51, S. $545-551$.

60 R. Green, J. B. Mendel, M. E. Hotvedt, J. Gray, L. Smith, Lesbians mothers and their children: A comparision with solo parent heterosexual mothers and their children, "Archives of Sexual Behavior" 1986, nr 7, s. 175-181.

OGRODY NAUK I SZTUK NR 2014 (4) 
przeznaczonych dla chłopców lub używały zabawek im przeznaczonych (na przykład karabinów). Można wnioskować, że matki homoseksualne bardziej tolerancyjnie odnosily się do podejmowanej aktywności przez swe dzieci i nie dzieliły zabaw na typowo chłopięce, czy dziewczęce, dając większą swobodę córkom wyboru preferowanej działalnoścí6152.

Jak młodzież i dorośli wychowujący się w rodzinie homoseksualnej postrzegają własną orientację? Okazuje się, że bardzo podobnie do osób dorastających w domach heteroseksualnych rodziców. Czternaścioro na szesnaścioro osób badanych przez M. del Mar González i F. López ${ }^{62}$, wychowywanych w rodzinach „tęczowych”, mówiło, że są heteroseksualistami i tylko dwie osoby uważały się za homoseksualistów. Jak piszą autorzy tych badań, podobną analizę przeprowadzono w Stanach Zjednoczonych, gdzie 90\% z badanych osób, których opiekunami byli geje, bądź lesbijki, deklarowało odmienną niż rodzice orientację seksualna, a tylko $10 \%$ z nich uważało się za homoseksualistów ${ }^{63}$.

W innym badaniu przeprowadzonym przez Sharon L. Huggins, na osiemnaściorgu adolescentach wychowujących się $\mathrm{w}$ rodzinach homoseksualnych utworzonych z par lesbijskich oraz osiemnaściorgu adolescentach z rodzin heteroseksualnych, analizowano orientację seksualną wychowanków rodzin "tęczowych". Wszystkie osoby z rodzin homoseksualnych uważały się za heteroseksualistów, z kolei jedna osoba wychowująca się w rodzinie heteroseksualnej uważała siebie za homoseksualistę ${ }^{64}$.

J. M. Bailey wraz ze wspótpracownikami ${ }^{65}$ przeprowadzili badania na osiemdziesięciu dwóch mężczyznach mających co najmniej siedemnaście lat, a wychowywanych przez ojców będących orientacji biseksualnej lub homoseksualnej. Okazało się, że ponad $90 \%$ z nich było orientacji heteroseksualneje. Przy analizie powyższych badań, należałoby jednak zwrócić uwagę, że mimo wykazanej orientacji heteroseksualnej przez większość z przebadanych mężczyzn, wzór wychowywania przez ojców homoseksualnych bądź biseksualnych niewątpliwie oddziałuje w pewien sposób na ich (wychowanków) świadomość. Dlatego można wysunąć wnioski, że by badania były reprezentatywne powinny być poszerzone o większą i bardziej zróżnicowaną populację osób badanych.

Warto przytoczyć wypowiedź dorosłej, już dwudziestosześcioletniej kobiety, dorastającej w domu w którym jej biologiczna matka była orientacji homoseksualnej i opiekowała się nią wraz ze swoją partnerką: "Zawsze zakochiwałam się w chłopcach. Jedna rzecz mnie zastanawiała zawsze, czy będę lesbijką? Bo skoro twoja mama nią jest, to myślisz sobie o tym, wiele razy o tym myślisz... nie dlatego, że przyciagasz kobiety, ale dlatego, że mówisz »skoro moja mama jest lesbijka, to pewnie ja nią będę też«, ale nie, to jest niemożliwe, ponieważ częściej spałam z koleżankami i częściej się z nimi widywałam niż z kimkolwiek, ale bardziej niż kogokolwiek wolę mężczyzn! Nie mam żadnych wątpliwości" ${ }^{\prime \prime 7}$.

Analizując powyższe, nic nie wskazuje na to, że orientacja seksualna opiekunów mogłaby w dużej mierze determinować orientację seksualną wychowywanych przez nich dzieci. Wychowankowie z rodzin ",tęczowych" definiują swoje zainteresowanie płcią przeciwną $\mathrm{w}$ bardzo zbliżonym wymiarze w porównaniu do dzieci $\mathrm{z}$ rodzin heteroseksualnych, jednak wypowiadają się w tym względzie z większą swobodą ${ }^{68}$. W związku z czym, można hipotetycznie założyć (by mieć pewność należałoby przeprowadzić większą liczbę badań longitudinalnych), że orientacja homoseksualna rodziców wychowujących dzieci nie przesądza jednoznacznie o takiej samej orientacji seksualnej swego potomstwa, zwłaszcza, że na orientację seksualną składa się również wiele innych czynników ${ }^{69}$.

\section{Podsumowanie}

Podsumowując wszystkie powyższe informacje i dane, bazujące na badaniach przeprowadzanych przez różnych badaczy, można wskazać kilka podstawowych aspektów wyróżniających funkcjonowanie rodzin homoseksualnych i ich dzieci spośród rodzin heteroseksualnych i ich członków. Przede wszystkim, wiadomo, że środowisko rodzin "tęczowych" nie stanowi źródła zagrożenia dla rozwoju dzieci i nie determinuje wykształcenia się u ich wychowanków orientacji homoseksualnej. Członkowie rodziny dobrze radzą sobie w relacjach z otoczeniem oraz w środowisku szkolnym

\footnotetext{
$61{ }^{52}$ Tamże, s. 175-181.

62 M. del Mar González, F. López, dz. cyt., s. 12.

63 Tamże, s. 12.

64 S. L. Huggins, A comparative study of self- esteem of adolescent children of divorced lesbian mothers and divorced heterosexual mothers, [w:] F. W. Bozett (red.), Homosexuality and the family, New York 1989, s. 123-135.

65 J. M. Bailey, D. Bobrow, M. Wolfe, S. Mikach, Sexual orientation of adult sons of gay fathers, "Developmental Psychology" 1995, nr 31, s. $124-129$.

66 Tamże, s. 124- 129.

67 M. del Mar González, F. López, dz. cyt., s. 12.

68 Tamże, s. 1-22.

69 M. Beisert, Rozwój psychoseksualny czlowieka, [w:] Z. Lew-Starowicz, V. Skrzypulec (red.), Podstawy seksuologii, Warszawa 2010, s. 83-91.
} 
i edukacyjnym. Są oceniani jako otwarci i tolerancyjni, a same rodziny homoseksualne tworzą prawidłowe środowisko (stawia się na rozmowę, argumentację, zaufanie, szacunek) dla wczesnego i późniejszego rozwoju swoich pociech. Dojrzewanie dzieci z rodzin „tęczowych upływa w normatywnym i harmonijnym środowisku rodzinnym i ich rozwój nie różni się znacząco, w większości obszarów, w porównaniu do ich kolegów z rodzin heteroseksualnych. Ponadto, rodziny homoseksualne szczególnie wyróżniają się względem wagi, jaką przywiązują w edukacji swych dzieci do wartości, takich jak równość, szacunek i tolerancja w stosunku do bliźnich ${ }^{70}$.

Należy wspomnieć, że analizując dane zamieszczone w tekście, trzeba mieć na uwadze usytuowanie demograficzne przeprowadzonych badań i związane z tym różnice między innymi te społeczno- kulturowe, mające wpływ na uzyskanie takich a nie innych wyników. Mianowicie, badania przeprowadzano w Hiszpanii czy Stanach Zjednoczonych, czyli w krajach w których tolerancja w stosunku do osób orientacji homoseksualnej oraz par i rodzin tęczowych jest stosunkowo wyższa aniżeli w Polsce (może mieć to związek między innymi z możliwością prawnej legalizacji związków lesbijskich i gejowskich). W związku z czym, należy w sposób niezwykle ostrożny uogólniać powyższe dane, tudzież przekładać je na grunt Polskiej rzeczywistości, która różni się od rzeczywistości społeczno-kulturowej (i nie tylko) w Hiszpanii oraz Stanach Zjednoczonych).

Mając na uwadze powyżej wspomniane ograniczenia w uogólnianiu wniosków z analizowanych badań, w ramach podsumowania można także napisać, że środowisko rodziny homoseksualnej okazuje się być również odpowiednim do wychowywania dzieci i nie determinuje wystąpienia u nich problemów rozwojowych, czy psychospołecznych. Jak pokazują badania, każda rodzina (niezależnie od płci rodziców) jest tak samo odpowiednią do posiadania potomstwa i przekazywania im wartości rodzinnych, pod warunkiem, że okazuje im miłość, szacunek, nie podejmuje żadnych form przemocy psychicznej, fizycznej i nawiązuje stałą komunikację opartą na słuchaniu opinii drugiej osoby oraz na kompromisie ${ }^{71}$.

\section{BIBLIOGRAFIA}

[1] Bailey J. M., Bobrow D., Wolfe M., Mikach S., Sexual orientation of adult sons of gay fathers, "Developmental Psychology" 1995, nr 31

[2] Bardziejewska M., Okres dorastania. Jak rozpoznać potencjał nastolatków?, [w:] Brzezińska A. I. (red.), Psychologiczne portrety cztowieka, Gdańsk 2005.

[3] Beisert M., Rozwói psychoseksualny człowieka, [w:] Lew-Starowicz Z., Skrzypulec V. (red.), Podstawy seksuologii, Warszawa 2010

[4] Cooper L., Cates P., Too High a Price: The Case Against Restricting Gay Parenting, New York 2006.

[5] Flaks D., Ficher I., Masterpasqua F., Joseph F. G., Lesbians choosing motherhood: A comparative study of lesbian and heterosexual parents and their children, "Developmental Psychology" 1995, nr 31.

[6] Fulcher M., Chan R. W., Raboy B., Patterson Ch. J., Contact with grandparents among children conceived via donor insemination by lesbian and heterosexual mothers., "Parenting: Science and Practice" 2002, nr 2.

[7] Gartrell N., Banks A., Reed N., Hamilton J., Rodas C., Deck A., The National Lesbian Family Study: 3. Interviews with mothers of five-year-olds, "American Journal of Orthopsychiatry" 2000, nr 70(4).

[8] Golombok S., Spencer A., Rutter M., Children in lesbian and single-parent households: Psychosexual and psychiatric appraisal, "Journal of Child Psychology and Psychiatry" 1983, nr 24.

[9] Green R., Mendel J. B., Hotvedt M. E., Gray J., Smith L., Lesbians mothers and their children: A comparision with solo parent heterosexual mothers and their children, "Archives of Sexual Behavior" 1986, nr 7.

[10] Huggins S. L., A comparative study of self- esteem of adolescent children of divorced lesbian mothers and divorced heterosexual mothers, [w:] Bozett F. W. (red.), Homosexuality and the family, New York 1989.

[11] Kaim A., Gugniewicz A., Edukacja bez wykluczenia. ABC wsparcia dla rodzin zagrożonych wykluczeniem spotecznym. Informator dla nauczycieli inauczycielek, Gdańsk 2007.

[12] Kirkpatrick M., Smith C., Roy R., Lesbians mothers and their children: A comparative survey, "American Journal of Orthopsychiatry" $1981, \mathrm{nr} 51$.

[13] Oliva A., Parra Á., Antolín-Suárez L., Arranz E., Martín J. L., Lamb M., Diversidad familiar y desarrollo psicológico: un estudio pionero realizado en España, [w:] Arranz Freijo E., Oliva Delgado A. (red.), Desarrollo psicológico en las nuevas estructuras familiares, Madrid 2010.

[14] Ostoja-Zawadzka K., Cykl życia rodzinnego, [w:] De Barbaro B. (red.), Wprowadzenie do systemoowego rozumienia rodziny, Kraków 1997.

[15] Patterson Ch. J., Children of the lesbian baby boom: behavioral adjustment, self-concepts, and sex-role identity, [w:] Greene B., Herek G. (red.), Contemporary perspectives on lesbian and gay psychology: Theory, research and application, Beverly Hills 1994.

[16] Patterson Ch. J., Families of the lesbian baby boom: Parents' division of labor and children's adjustment, "Developmental Psychology" $1995, \mathrm{nr} 31$.

[17] Patterson Ch. J., Lesbian and gay parenting, Washington 2005.

[18] Plopa M., Psycholocia rodziny: teoria i badania, Kraków 2005.

[19] Seligman M., Walker E. F., Rosenhan D. L., Psychopatologia, Poznań 2003.

\section{Netografia}

[20] del Mar González M., López F., ¿Quéhemos aprendido de las familias homoparentales en España?, http://www.fsc.ccoo.es/comunes/recursos/99922/ doc21513_Que_hemos_aprendido_de_las_familias_homoparentales_en_Espana_pdf, 11.03.2014.

70 A. Oliva, Á. Parra, L. Antolín, E. Arranz, J. L. Martín, M. Lamb, dz. cyt., s. 143-156.

71 Tamże, s. 143-156. 